\title{
A Plan for the Reform of Legal Procedure
}

\author{
7 HE following is the main outline of a plan for the reform of \\ legal procedure:

\section{Rules of Court}

Most of the rules of legal procedure are not matters for legislatures, but matters for the courts. Hence the first and most inportant thing is the substitution of rules of court for statutory legislation upon this subject. The second thing and next in importance is the provision that all these rules of court shall be directory and not mandatory.

The courts, by this plan, would be vested with the control of legal procedure. If the judges were all of the right sort, it might be sufficient to leave everything to rules of court. But because of the uncertainty as to what judges might be selected for this task and in order to have uniformity throughout the country, it is better not to make this control absolute and unlimited, but to set some limits as to jurisdiction and fundamentals by constitutions and legislation. Otherwise the control is complete. This is the vital thing in this plan for the reform of legal procedure. If this part of the plan is understood, other features will offer no great difficulty.

This reform is a great departure from former practice in the United States, and yet it is in line with social and legal development. That society in general is demanding this sort of reform is shown by the sort of procedure which obtains in the executive boards and administrative commissions, which within the last few years have been established in ever-increasing number in our land for the purpose of doing certain forms of judicial work. That the legal profession is also beginning to demand this sort of reform is shown by the procedure which has been adopted by our juvenile courts, by our municipal courts, by the new practice act recommended by the Board of Statutory Consolidation of the State of New York. by certain other state courts, by the equity rules of the Supreme Court, and by the fact that this form has repeatedly been endorsed by the Annerican Bar Association and that it is being endorsed by an increasing number of state bar associations. The best thought of the legal profession is back of the plan. ${ }^{2}$

1 Dean Roscoe Pound of the Law School of Harvard University, and also dean of the law school men of the United States, has for years been 
The English people adopted the plan of regulating legal procedure by rules of court instead of by legislative enactments as long ago as 1873. Since that time English legal procedure has been revolutionized. Yet we Americans proceed along in our same old bungling, clumsy way without making an effort to copy the English reforms!

The courts are the proper bodies to regulate legal procedure. Legal procedure is appropriately not a matter of codification, but a matter for simple rules of court. Substantive law is inproved by codification. The more legal procedure is codified, the worse it becomes. Where legal procedure is regulated by statute, the courts are powerless to alleviate from such statutory rules, and legal procedure necessarily becomes a matter of right. Where legal procedure is statutory, the courts more and more fail to come to the merits of the controversy, but sinply multiply adjudications upon matters of inere procedure.

The old system of trying cases under statutory rules has been productive of untold evils. The first and greatest evil has been the exaltation of legal procedure. Legal procedure has become an end instead of a means. The trials of cases have been concerned less with the substantive rights of the parties, and more over the mere rules of procedure by which justice is supposed to be administered. Attorneys and judges seein almost to have turned their backs upon the important things of substantive law, and to have wandered off until they have lost theinselves in the labyrinthine mazes of adjective law. In both the Federal and state courts over one-half of the cases appealed to the supreme courts have involved no questions of substantive law at all. ${ }^{2}$

Other consequences of making legal procedure a matter for legislative instead of judicial control have been delays, technicalities, uncertainties, and expense.

The average length of a lawsuit in the United States has been appalling. One California case lasted twenty-two years. ${ }^{3}$ It has been not unusual for a case to last from five to ten years. Delays

advocating this reform. His articles thereon may be found in the Report of the American Bar Association, Vol. XXIX (1906) p. 395; 4 Illinois Law Review, 388, 491; 22 Green Bag, 438. The best law school men agree with Dean Pound. Professor Morgan, now of Yale University Law School, has an illuminating article upon this subject in 2 Minnesota Law Review, 81 .

2 American Bar Association Report, Vol. X (1887) p. $317 \mathrm{ff}$.

${ }^{3}$ Cox v. McLaughlin (1872) $44 \mathrm{Cal}$. 18, (1873) $47 \mathrm{Cal}$. 87, (1888) 76 Cal. 60, 18 Pac. 100,9 Am. St. Rep. 164; and see Cox v. Delmas (1893) 99 Cal. 104, 33 Pac. 836. 
have occurred in the impaneling of juries, in the introduction of evidence, and in the perfecting of an appeal. Perhaps the two chief weapons for procuring delay have been new trials and reversals. But whatever the causes for the delay, the results have always been unfortunate. Justice delayed is too often justice denied.

The technicality resulting from making legal procedure a matter of legislation has been, if anything, even worse than the delays. A day's time of a busy court, for example, has been taken over the question of whether or not an action is a tort action or a contract action. The instructions of trial judges have been reviewed for their academic correctness. The courts have been trying records instead of cases. They have been writing long dissertations upon questions of procedure instead of deciding real controversies.

The uncertainty resulting from the attempt to administer justice by rules formulated by legislatures has been another appalling indictment of the system. The old system has become so bad in this respect that it is little more than a legal game. The administration of justice hangs on the outcome of such game. The consequence is that honest litigants shun the court room, poor litigants do not stand an even chance with rich litigants, and litigants with good cases often lose them because their attorneys do not play the game as well as they might have played it.

The expense incident to the administration of justice where legal procedure is exalted, as it necessarily has to be where the rules of procedure are codified, has been almost prohibitive. It has been greater than it ought to be both to the state and to the litigants. The cost to the state of damage suits for a long period of years in many parts of the United States has been more than all the verdicts rendered. The cost to the litigants has become so great that it has become almost a scandal, and there has been a loud cry for legal aid societies, small claims courts, and public defenders, in the hope that in this way some of the burdens of litigation might be alleviated. But these so-called reforms have not accomplished any permanent good. They have not gone to the root of our legal troubles. ${ }^{4}$

As a consequence of all these defects and evils which are incident to the old system, society is demanding a reform. The only way that any satisfactory reform can be worked out is by the abolition of the old system and the establishment of a new. It is

${ }^{4}$ John R. Rood, The Cost of Public Justice, 12 Illinois Law Review, 540. 
impossible to remedy the present system by patchwork. The trouble with the present system is not that the rules of the system are wrong so much as that the system itself is wrong.

The principal trouble with the old system is that there is too much of it. If the old system is to be retained, if the different rules of legal procedure are to be left on our statute books, they might as well be left just as they are. If we are going to continue to have statutory rules of pleading and mandatory rules of evidence, and statutory rules of trial and appellate practice, we might as well keep those which we have as to fly to others of which we do not know, and which would turn out to be just as bad in accomplishment as those which we now have. The old rules have been improved and improved until they can be improved no more. The alternative is either to keep them and make the best of them or to discard them altogether. Society demands a reform. Hence it would seem that the only alternative is to discard them. The remedy - the only remedy - therefore, is the repeal of the old system and the adoption of a new system which is better adapted to social ends. Of course it is going to be hard on many members of the legal profession, who are well trained in all the old rules, to coinpel them to give them up, and learn other new rules. But the welfare of society dernands it, and I believe that the legal profession will rise to the occasion in this crisis as it has in so many other crises in the history of our country.

The great objection to the rules of legal procedure is not that they are wrong, but that they have been outgrown and are unnecessary and antiquated. For lawyers to continue to use these old rules of legal procedure is as bad as it would be for farmers to continue to use the old wooden plow instead of the modern gang plow, or the old hand sickle instead of the modern harvester and binder. The farmers of today have abandoned all of the ancient farm tools for the most modern agricultural machinery, but the attorneys are still using the old primitive legal tools of their ancestors. Why should not the legal profession adopt and use the most modern and the best legal tools for the administration of justice?

While the plan proposes to reform legal procedure by making it a matter for rules of court, it does not propose to give the courts an arbitrary power in this respect. It proposes to insure a genuine reform by safeguarding certain fundamental matters. Soine of these fundamental matters are already safeguarded by the constitu- 
tions of the states and of the United Sattes. These and other necessary matters are, according to this plan, to be safeguarded by a brief act of the legislature. Herein we shall set forth the features which should be incorporated in this new practice act.

\section{Pleading}

Notice pleading should be substituted for the present system of issue pleading. There are some members of the legal profession who perhaps might be startled by this suggestion. I have no doubt that there are some attorneys who think there is no other way of pleading than issue pleading. A sufficient answer to this objection is the statement that issue pleading is solely characteristic of the American system. No other nation on earth has any such system, and the municipal courts of Chicago and the courts of Michigan in this nation have adopted notice pleading. If other nations are able to try cases on some other system of pleading than issue pleading, it ought at least to show that it is possible for us to do so in the United States. The present English system is a compromise which retains essential fact pleading in part, adopts notice pleading in part, and for the rest makes all pleading unnecessary. Many members of the English bench and bar, during the discussion which preceded the adoption of the modern English system, advocated the total abolition of pleading. Notice pleading would entail less of a change and would be more easily put into operation by our bench and bar than the English system, and after adoption would be a better system, and hence it has every argument in its favor. ${ }^{5}$

The Practice Act should require as a mandatory matter that all pleading should be according to the theory of notice pleading. The rules of notice pleading should be left to the courts for formulation and should be directory.

\section{Practice}

In the matter of trial and appellate practice, the administration of justice should be placed in the hands of the judges instead of in the hands of attorneys. In addition, appellate courts should be required always to render final judgment and given the power to make declarations of rights.

5 Professor Whittier, of the Law School of Leland Stanford Junior University. has explained the system of notice pleading so fully and presented the arguments therefor so completely in 31 Harvard Law Review, 501, that rather than go into arguments and explanations here, the reader is referred to his discussion. 
This reform requires every step in the trial of the case to be taken under the direction and supervision of the court. No notices would ever be given by one party to another. Every notice would come from the court. The pleadings would have to be submitted to the judges for approval. The entire conduct of the case would be in the hands of the judges. The judges would do the initial and primary work of impaneling the juries and examining witnesses. Any additional work by counsel would be subject to strict control by the court. No counsel at all would be necessary if the litigants wished to forego the same, as they well might in small claims cases. Experts would be called by the court instead of by the litigants. most of the proceedings would be oral, and the clerk would take minutes and write them out. The abominations of new trials and reversals for technicalities would be abolished, and in place thereof the appeals would take the form of a rehearing, and the appellate court would always render final judgment. In order to avoid unnecessary litigation the courts would also be empowered to make declarations of rights.

The above points would have to be covered by a Practice Act. All other details should be left to directory rules of court.

The above essentials of practice have already been adopted by the English courts. In England these reforms have come to pass very largely through the efforts of the judges themselves. In the United States, apparently, it is out of the question to hope for such a reform from the judges through voluntary action. Therefore, there is a necessity for legislation. The English have reformed their appellate practice by amalgamating all of the courts of the realm into one court with many subdivisions. This reform is desirable, but it could not be brought to pass in the United States without the amendment of constitutions. The same result, however, can be accomplished without the amendment of constitutions by requiring the appellate courts always to render final judgment.

\section{EVIDENCE}

In the matter of evidence, not many of the rules of evidence should be abolished; but with a few exceptions they should be eliminated as mandatory rules in the courtroom. Knowledge of the rules of evidence should be required by every attorney before admission to the bar, and especially of every judge before he is placed on the bench. But these rules should not be obtruded into the trial of the case. Evidence should not be admitted or excluded according to any rules of evidence. Certain constitutional and 
statutory rules as to what shall be evidence and how much evidence shall be required must, however, remain mandatory, and they should be incorporated into a Practice Act. Other rules of evidence might well be made directory rules of court. But for the most part the rules of evidence should be a part of a lawyer's education. ${ }^{\circ}$

There is no objection to the rules of evidence. The objection to many of them, however, is that they are unnecessary. Cases are tried just as well by executive boards, where none of these rules of evidence are observed except unconsciously, as by the regular judicial tribunals, where all the rules of evidence are observed. Most of the rules of evidence would hardly be appropriate in a courtroom where the judges were doing the primary work of examination of witnesses. Hence it may be said that, with the exceptions named, the only rules of evidence which should be tolerated are those which are merely directory rules of court and those the knowledge of which makes the judges better prepared to conduct the trial of cases. Because of their knowledge of the rules of evidence, for example, judges ought to refrain from asking foolish questions. But if they should not do so, it would not be ground for legal objection or reversible error.

The reform involved in the above plan would have to be brought about by the abolition of all the present rules of legal procedure, and by the substitution in the place thereof of rules of court. These rules should be drafted under the authority of the supreme court of the state, according to the few fundamental limitations which have been outlined above. All statutory and constitutional provisions should be mandatory upon the courts in their work of drawing up the rules of court, but all of these rules of court when once drawn up should be directory only and never mandatory. It should be "up to the courts" to see that their rules are observed.

\section{RESULTS}

The results which would follow from the adoption of the above plan for the reform of legal procedure are apparent. The delays, the technicalities, the uncertainties, and the expense of the old procedure would disappear. The court would again be admin-

${ }^{6}$ Dean John H. Wigmore, of Northwestern University Law School, has given a learned and helpful discussion of this question in the preface to his Supplement, 2nd ed. (1914), to his Treatise on Evidence, pp. xix to $\mathrm{xx}$, and xxii to xxviii. 
istering justice as the people of the country desire to have it administered. The judicial work which has been in the past taken away from the courts and given to executive boards would little by little again be given back to the courts, where it belongs. The new practice would shift the responsibility for the administration of justice from the legislature to the court. The judges would not be able to escape responsibility for the maladministration of justice by blaming it on fixed statutory rules, or upon the attorneys. The rights of the parties would be brought to the foreground, and the details of legal procedure would be relegated to the background. The bench would be stimulated to a higher degree of efficiency, and the bar would be prevented from interposing technical objections which do not go to the substantial rights of the parties. The time of the appellate courts would be conserved by not requiring them to review questions of procedure. The general result would be greater expedition, greater simplicity, greater certainty, less expense. This is proven by the history of the English courts since 1873. One English judge, according to estimate, is now dispatching as much legal business as twenty American judges, and not at the sacrifice of justice, but in the attainment of it. Legal procedure would become what it ought to be-a means for the administration of justice, and not an end.

Of course it must be admitted that much of the success of the reform would depend upon the judges and the bar as a whole. If the bench and bar should be antagonistic to the new reform, they might be able almost to nullify its good effects. This was what was really done with the so-called code reforms. The attorneys of the present should learn a lesson from the past, and not make the mistake which was made when the attempt was made to reform the common law procedure by the so-called code procedure. If the reform is to be the success it ought to be, attorneys instead of combating and opposing it must loyally and whole-heartedly support it, and thus make it accomplish all it is capable of accomplishing for the common good.

Hugh E. Willis.

University of North Dakota. 